v. 8, n.2

Vitória-ES, Apr. - Jun. 2011.

p. $42-65 \quad$ ISSN $1808-2386 \quad$ DOI: http://dx.doi.org/10.15728/bbr.2011.8.2.3

\title{
Students' loyalty and retention pattern for higher education institutions: a theoretical study based on the relationship marketing
}

\author{
Fabio Vinicius de Macedo Bergamo ${ }^{\dagger}$ \\ Adventist School of Bahia \\ Antônio Carlos Giuliani ${ }^{\Omega}$ \\ Methodist University of Piracicaba \\ Lesley Carina do Lago Attadia Galli ${ }^{*}$ \\ UNISEB COC
}

\begin{abstract}
The relationship marketing shows itself to be essential in order that the relation between schools and students happens. This approach leads organizations to develop relationships directed to the retention and loyalty. The present paper aims to create a pattern to measure the loyalty and retention of the students in Brazilian higher education institutions. Therefore, an exploratory and qualitative theoretical research about the theme was carried out. As the main result, we have the elaboration of the Pattern of Loyalty and Retention of Students for Higher Education Institutions, which presents the following aspects as variables: satisfaction, perceived quality, social integration, academic integration, cognitive commitment, commitment with the aims, commitment with the professional activities, commitment with the family, commitment with non-academic activities, emotional commitment, reliance and loyalty.
\end{abstract}

Keywords: Loyalty; retention; higher education institutions.

Authors' correspondence*:

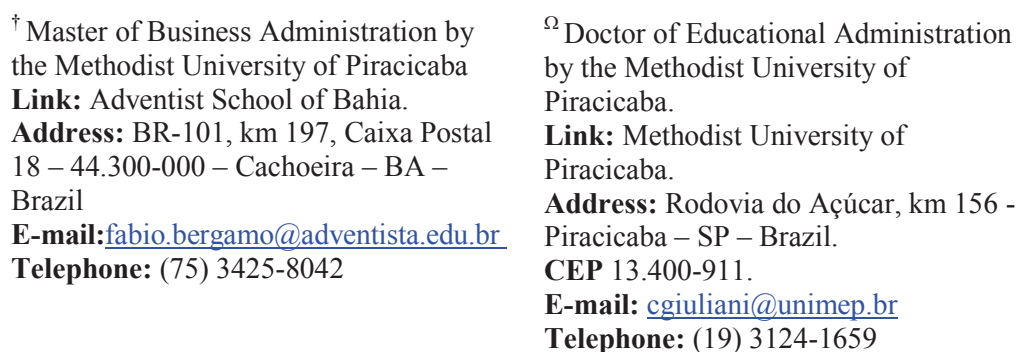

\footnotetext{
${ }^{*}$ Doctor of Business Administration by FEA -USP.

Link: UNISEB COC.

Address: 1600 South Eads 127-N, Washington DC, USA.

Rua Abrahão Issa Halack 980 Ribeirania

- Ribeirao Preto - SP - Brazil -

CEP 14096-160

E-mail: lesleyattadia@uol.com.br Telephone: (16) 9975-0502
}

Editor's Note: This paper was accepted by Antonio Lopo Martinez. 


\section{INTRODUCTION}

The growing competition in the educational sector brought to light the relationship marketing reality in the educational institutions (CZARNIAWSKA; GENELL, 2002). Within the marketing relational orientation, the client retention by means of the loyalty management can be considered a powerful strategy to the competitiveness survival and maintenance in the educational institutions (GREMLER; BROWN, 1999). In the educational field, to retain enrolled students (clients) is as important as to attract and to enroll them (KOTLER; FOX, 1994).

It is observed that the school dropout rates in the Brazilian higher education gets to $51 \%$, which makes us believe that the dropout is the greatest challenge of the educational managers, considering that this factor compromises the financial health and putting in risk the private institutions survival (PEREIRA, 2003).

To find out the causes of school dropout is a subjective task and has been the focus of several researches abroad, for instance: TINTO, 1975; 1993; WETZEL; O'TOOLE; PETERSON, 1999; HENNIG-THURAU; LANGER; HANSEN, 2001; ROWLEY, 2003; YORKE and LONGDEN, 2004; HERZOG, 2005; STRATTON; O'TOOLE; WETZEL, 2007. In Brazil, this theme has been already covered by the following authors: ANJOS NETO, 2003; PEREIRA, 2003; BIAZUS, 2004; LANZER, 2004; GAIOSO, 2005; LIMA, 2006. However, there were few studies which pursued a "bridge" between both approaches, of marketing and of education. Within this context, the present paper aims at the creation of a pattern to measure the student's loyalty and retention in Brazilian higher education institutions.

\section{THEORETICAL FRAMEWORK}

The theoretical review is organized in the following topics: marketing relational approach, clients' loyalty, client relationship patterns, loyalty antecedents, clients-students retention in the higher education and clients-students retention in the higher education patterns.

\subsection{Marketing Relational Approach}

Hennig-Thurau and Hansen (2000) affirm the existence of three approaches for the theoretical studies in relationship marketing. The first is the behavioral perspective, which focuses on the relationship constructs and on the client retention evaluation, as well as the internal company relations. The second is the perspective in the relationship network. Finally, 
the third approach is the neo-institutional economic perspective, which uses the economic theories to explain the relationships. It is relevant to highlight that this paper is bound to the behavioral approach. Within the behavioral perspective, there are several definitions to relationship marketing, indicating that it is a process that tries to attract, maintain and consolidate the clients' long-term relationship, through the sharing of benefits and successful relational exchanges (KOTLER, ARMSTRONG, 2003).

It can be observed that the majority of the definitions found in the literature see the relationship marketing as a process. Nevertheless, none of them is worried to describe this process in a deeper way. This contributes for the reservations that are still done about the relationship marketing as a theory, paradigm or way of thinking (GRÖNROOS, 2004).

\subsection{Clients Loyalty}

Oliver (1999) shows that, besides the behavioral aspects, loyalty also includes attitudinal dimensions, classifying it as a narrow commitment between repurchase behavior and adherence to a product/service in a consistent way in the future. According to Clancy and Shulman (1995), the attitudinal loyalty reflects what the buyers fell and think about a certain product or service.

Akarapanich (2006) states that the client loyalty intents are important to the marketing because they serve as predictors of the consumer's purchase decisions. Complementing this idea, Kumar (2007) emphasizes that the attitudinal loyalty has to be cultivated, resulting in a long and productive relation between the company and the client. Within this context, the loyalty attitudinal aspect understanding is essential to the development of a relationship marketing strategy. Following this idea, Oliver (1999), developed a taxonomic study in which the construct is presented in four steps:

- Step 1 - cognitive loyalty: based on beliefs, on information about the product and on recent experiences with the object, in a way directed to the preference of a brand in detriment to another. It is a stage which allows the analysis and comparison of certain features of the product/service;

- Step 2 - affective loyalty: where the relation between attitude and a brand is developed, through the accumulation of successful purchases and uses which result in the client's satisfaction. It is in this step that the commitment starts to become deeper, avoiding even more the change of supplier or brand; 
- Step 3 - conative loyalty: where there is a commitment much more developed, resulting from several positive scenarios of affection for the brand, which leads to the repurchase behavior; and

- Step 4 - action: it is the loyalty peak, in which the client turns his intents into action, being his desire greater than the obstacles that may appear.

We can notice that the first two steps are a kind of preparation for a state of actual loyalty, which is developed in its fullness in the last two steps, the conative and the action steps (EVANSCHITZKY; WUNDERLICH, 2006).

It is also relevant to highlight that it seems that there is, in the common sense, a convergence between the concepts of loyalty, fidelity and retention, being convenient to differentiate them. Griffin (1998, p.12) defines fidelity as "non-random purchases done over the time by any decision-making unit". The fidelity only emphasizes the behavioral aspect in detriment to the attitudinal one, in the extent that it focuses on the purchases repetition (SCHULZ, 1998).

On the other hand, in relation to the difference between clients' loyalty and retention, it is worth observing that the retention may be defined as a company's ability to maintain the already acquired consumers (JAMAL, 2004), offering them, besides the product for purchase, a relationship pattern within a specific period (SHAJAHAN, 2006). SO, it can be said that the retention of clients is the basis of the relationship marketing and, thus, of loyalty (PAYNE; FROW, 2000).

\subsection{Client Relationship Models}

The retention (or deflection) is, in the majority of the times, caused by an emotional impulse. In this way, it is indispensable to know the client's desires and needs, as well as the implicit reasons to maintain or leave a relationship (HENNIG-THURAU; HANSEN, 2000).

Dwyer, Schurr and Oh (1987) were the first to outline a model, named "Relationship Development Process", which approached the buyer/vendor relationship process in five phases: conscience, exploration, expansion, commitment and dissolution. This model was the base of posterior studies and is still used as the framework for the relationship study in several fields. 


\subsubsection{Relationship Quality Model}

From this idea, Hennig-Thurau and Klee (1998) developed a clients retention model called "Relationship Quality", which is presented in Figure 1 and is composed of the following variables:

- Client satisfaction: company-s developments evaluation done by the client, according to their expectations (WESTBROOK; OLIVER, 1991);

- Reliance: credibility noticed by the client (WONG; SOHAL, 2002);

- Commitment: state in which the client demonstrates that they wish to keep the relationship with the company or product (HENNIG-THURAU; KLEE, 1997); and

- Noticed quality: essential for client retention (HOUGAARD; BJERRE, 2003).

The Relationship Quality Model presupposes that the relationship quality is a variable that helps to measure the clients' relationships management success (HENNIG-THURAU; HANSEN, 2000). A high quality relationship contributes for the positive perception of the clients as for the services, substantially increasing the chances of establishing a long-term relationship (CROSBY; EVANS; COWLES, 1990).

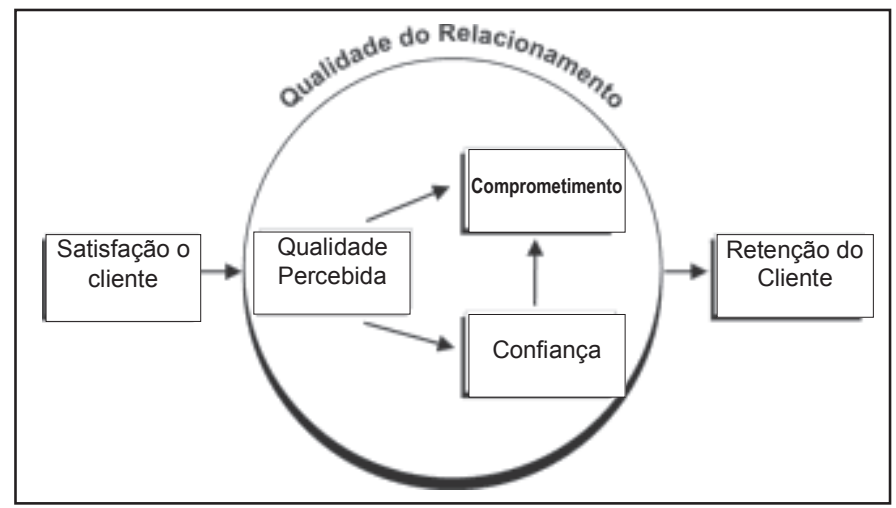

Figure 1. "Relationship Quality" conceptual model

Source: Adapted from Hennig-Thurau and Klee (1998)

\subsubsection{Relationship Quality Integrative Model}

When focusing on the services sector and understanding the importance of developing and keeping growing relationships with clients as a major point to be followed, HennigThurau, Gwinner and Gremler (2002) highlighted two types of benefits that may be obtained by the companies. They are:

- Consumer's relational benefits: derive from the idea that mutual benefits must occur in order that the wish to go on with a relationship is kept (LILJANDER, 
2000). Competitive advantages may be created, in the extent that it becomes difficult for other companies to replicate theses benefits (HENNIG-THURAU, GWINNER and GREMLER; 2000). Hennig-Thurau, Gwinner and Gremler (2002), on the other hand, classified the relational benefits into client's reliability benefits; social benefits (client's personal interaction with the employees) and special treatment benefits (elapsing from the clients' perception); and

- Relationship quality: multi-way approach and focused on the long-term which focuses on the clients' transactions evaluation and on their relationship (HENNIGTHURAU; GWINNER; GREMLER, 2002). In the view of Crosby, Evans and Cowles (1990), the relationship quality is reached when the uncertainties noticed by the clients reduce in the moment of purchase.

The combination of these two theoretical approaches (relational benefits and relationship quality) generates a new proposal called Integrative Model, elaborated by Hennig-Thurau, Gwinner and Gremler (2002) for the services sector. The model proposed by Hennig-Thurau, Gwinner and Gremler (2002) was designed aiming to understand the factors that influence on the so-called relationship marketing "results". The authors present as one of the main results the client's loyalty, together with the word of mouth communication.

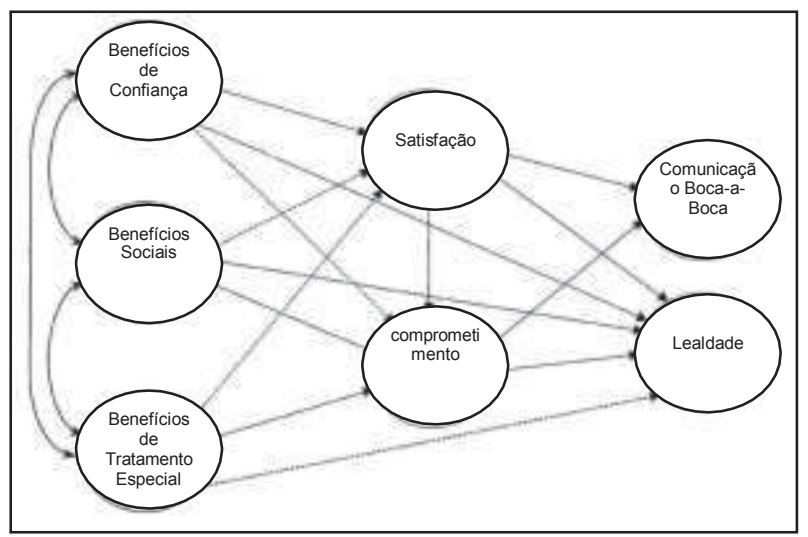

Figure 2. Relationship Marketing Integrative Model

Source: Adapted from Hennig-Thurau, Gwinner and Gremler (2002)

\subsection{Loyalty Antecedents}

The client's loyalty is motivated by the relation between the relational benefits and the relationship quality. From this presupposition, the loyalty antecedents are defined, being stood out: satisfaction, noticed quality, reliance, commitment. Each of these aspects is covered on the items that follow. 


\subsubsection{Satisfaction}

Studies show that the satisfaction is an initial and non-unique construct of the loyalty process, ceasing to be a future determining factor and becoming a predictive element of the client's repurchase intention (NAUDÉ; BUTTLE, 2001).

Matos and Henrique (2006) list some of the constructs essential to the consumer's satisfaction development:

- Quality: is the evaluation done by the market served with recent consumption experience. The service quality increase provides an increase in the client's satisfaction with this service; and

- Performance expectation: is a referential element, in which consumers "foresee" the experience they will have with a certain company, product or service. Oliver (1980) mentions the expectations with a direct and positive association with the client's cumulative evaluation. When he achieves his expectation positively, the client will be pleased. Nevertheless, the non-reached expectations result in displeasure (WIRTZ; BATESON, 1999).

\subsubsection{Noticed Quality}

The noticed quality, according to Zeithaml (1988, p.3) is "the consumer's judgment about the global superiority and excellence of a product". Parasuraman, Zeithaml and Berry (1988) emphasize the noticed quality as an attitudinal element.

In the services sector, the most notorious and disclosed way of measuring the noticed quality is the use of the SERVQUAL model, proposed by Parasuraman, Zeithaml and Berry (1988), which contemplates five dimensions:

- Tangibility: considers the physical facilities, the equipment used, as well as the personal appearance;

- Reliability: ability to execute the promised service in a safe and precise manner;

- Responsiveness: the wish of helping the clients and providing them with a ready service;

- Safety: knowledge and politeness of the employees, who are capable of inspiring confidence; and 
- Empathy: individualized care and attention that the company foresees for their clients.

According to Fullerton (2003), the services' noticed quality increment will probably lead to a client's loyalty increase.

\subsubsection{Reliance}

Reliance is also considered essential in the relationship quality and clients retention perspective (WONG; SOHAL, 2002).

One of the definitions of consumer reliance most used in literature is the one proposed by Moorman, Zaltman and Deshpandé (1992, p.315), in which reliance is defined as regarded as "the desire of providing with credibility an exchange partner to whom credibility can be given".

For Santos and Rossi (2002), the reliance involves issues regarding not only credibility (belief that the vendor has the required expertise to perform his job in an effective and reliable way), but also good-will (belief that the vendor creates special conditions in order that the exchanges happen, putting the clients interest above his own interests).

Sirdeshmukh, Singh and Sabol (2002) believe that the reliance in a service provider is developed by means of two elements:

- Front-line employee, exposed to "truth moments": the clients notice that the employee makes efforts to being useful and that he possesses the knowledge needed to serve them; and

- Management policies and practices: the organization develops techniques that improve both its performance and its potential obligations, benefits and burdens.

The client's reliance can also be regarded as a matter of justice. According to Barlow and Maul (2000), when the clients believe they are being treated in an unfair manner, they are first surprised and then disappointed, feeling that their confidence was "betrayed".

\subsubsection{Commitment}

According to Geyskens et al. (1996), the client's convictions in a commitment state indicate that remaining in the relationship will bring him more benefits than losses. In line with Hennig-Thurau and Klee (1997), the commitment is the antecedent of client's retention 
and loyalty, antecedent that is positively related and influenced by the other antecedents mentioned so far.

The commitment may be understood through the following dimensions (PRADO; SANTOS, 2003):

- Affective commitment: based on the sense of emotional preference of the client for the company, having a positive influence on the intention and desire of keeping and investing in the relationship, besides developing barrier in the pursuit of alternatives to this relationship. The affective commitment creates identification, shared values, sense of belonging, dedication and similarity on the part of the client regarding the brand-company (FULLERTON, 2003);

- Continuity or calculating commitment: according to Fullerton (2003), they focus on the concrete costs of services provider change and on the benefits of keeping the relationship. This approach has negative impacts on the relationship, since, consistent with Wetzels, de Ruyter and van Birgelen (1998), it influences the opportunism and the search for better alternatives by the client;

- Normative commitment: refers to the duty of remaining in the relationship;

- Instrumental commitment: considers stimuli, as prizes and punishments; and

- Behavioral commitment: contemplates the provider's perception in helping the partner with his needs.

\subsection{Clients-students retention in Higher Education}

Milliken (2007) sees the students' deflection issue within education as an "epidemic", which has been affecting the survival of educational institutions in all its levels.

In a definition by Berger and Lyon (2005, p.3), retention, in the higher education context, is the "ability of a Higher Education Institution (HEI) to successfully graduate the students who initially registered in the institution".

We can say that dropout indexes measurement is a prerequisite for an effective management of the clients-students retention (HERZOG, 2005). The students should also be segmented in specific study groups (DESJARDINS, 2003). In this regard, one can identify in literature the features most commonly used in the students segmentation within the higher education, namely: 
- Bemographic aspects: involve race and ethnic group, gender, marital status, age and level of society (REASON, 2003), and

- Educational aspects: involve financial help (student, holding a scholarship or not), academic performance, way of registration, prior education (public, private or communitarian school), shift (diurnal or nocturne), integrality (TINTO, 1993; STRATTON; O’TOOLE; WETZEL, 2007).

From the existing information, the institution must manage the students' retention. Kotler and Fox (1994) indicate that a "Retention Program" is a tool essential to this scenery, comprising the following activities:

- Establishment of a retention program commission;

- Evaluation of the retention situation;

- Determination of the causes that are leading students to leave the institution;

- Encouragement of a service attitude to the students;

- Creation of conditions that meet the admission objectives;

- Facilitation of the student's traffic in the institution facilities;

- Rendering of advisement and orientation; and

- Creation of a students-oriented environment.

When studying the financial cost-benefit relationship of the investment in students retention programs, Simpson (2005) confirmed that the HEI that have used this tool obtained returns of $450 \%$ to $650 \%$ upon the costs applied in the referred programs.

Rivas et al. (2007) show that the deflection indexes are actually higher among newly enrolled students or in the first years, decreasing at each year in which the student renews his registration until the degree course conclusion. Murtaugh, Burns and Schuster (1999) and Tinto (1999) show that the retention treatment aiming at the student in the first year is essential for his persistence, suggesting that the institutions implement orientation courses to these students, as well as HEI immersion programs, which motivates the student and make him feel part of the new community. This kind of action is very common in the United States and in European countries of Anglo-Saxon origin, but still incipient in the Brazilian reality. 


\subsection{Models for the Clients-students Retention in Higher Education}

Braxton and Hirschy (2005) describe that the studies about retention were carried out using several perspectives, such as the economic, the organizational, the psychological, the sociological and the interactionist perspectives.

Among them, the interactionist perspective seems to be the most compatible with the relationship marketing approach, since it focuses on the retention theme through the student's intimate relationship with his HEI, considering a series of relational and socialization factors, but keeping the approach of themes such as satisfaction and quality. The interactionist perspective constitutes a longitudinal view of the persistence/deflection process, resulting from the students' interaction with the HEI formal and informal dimensions.

\subsubsection{Student Integration Model}

The main model within the clients-students retention interactionist perspective is the model of Vincent Tinto (1975; 1993), identified as "Student Integration Model", which is based on the relationship between the student and his institution through his interaction with the process "actors": professionals (professors and others directly linked to the student) and classmates.

The respective model consists of six sets of variables in a causal sequence: pre-entrance attributes; initial commitments; academic integration; social integration; subsequent commitments; and results (decision between persistence and deflection). Figure 3 shows the Tinto’s (1993) model diagram.

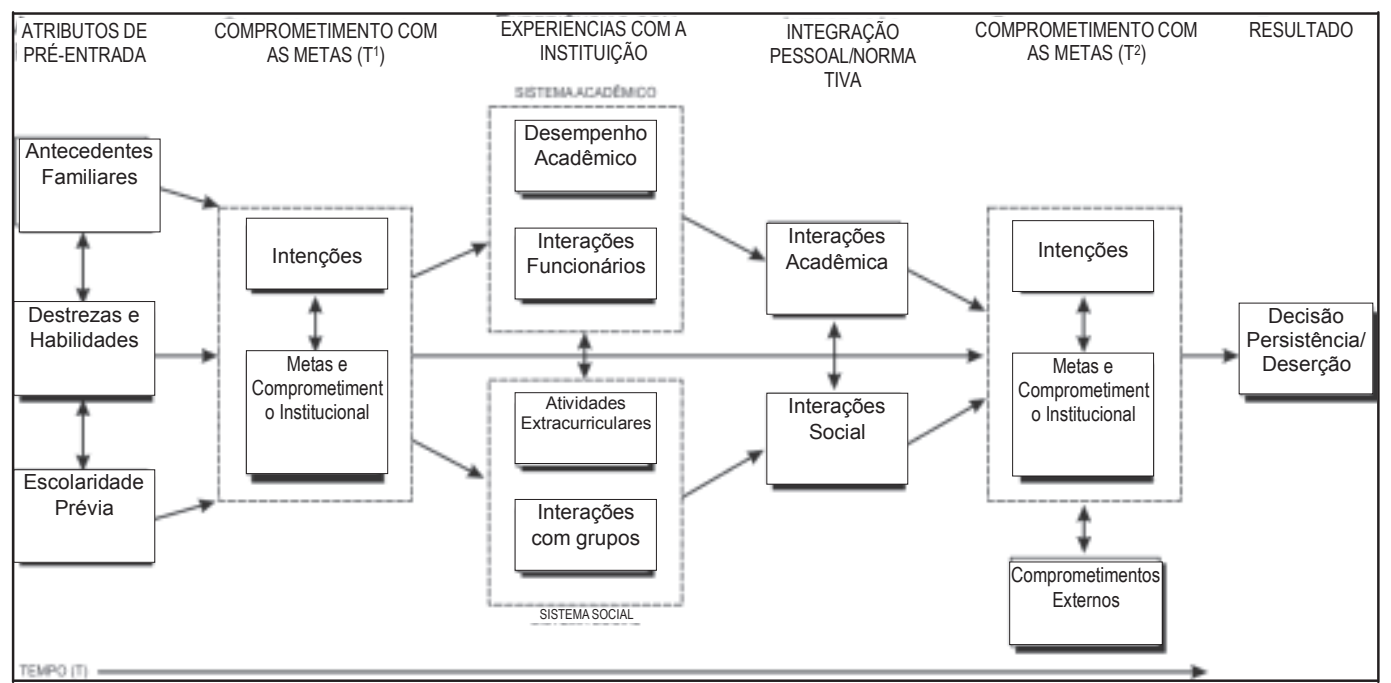

Figure 3 - Student Integration Model

Source: Adapted from Tinto (1993) 
The first influence suffered by the student comes before his effective entrance in the institution, by means of the pre-entrance attributes. They are (TINTO, 1993):

- Attributes and abilities: correspond to the individual's demographic variables, as well as to the students' educational aspects;

- Previous education: all the academic experiences in the primary and secondary educations; and

- Family history: aspects such as the family's socio-economic and cultural level, as well as the values that are supported by this family.

The model's next step is the goals outlined by the student himself. His commitment level with such goals, as well as his intention to graduate, or not, influences on the future retention decision. When the student enters the higher education with low expectations regarding the course conclusion, he has a great inclination towards deflection.

According to Tinto $(1975 ; 1993)$, the integration occurs in two dimensions:

- Academic integration: this dimension consists of structural and normative elements. The structural integration is the link that existents between the student and the structure availability in the HEI. The normative integration, on the other hand, regards the relationship with the group of professionals that is directed connected to the student, such as professors. These two views have an influence in the academic efficiency and in the student's intellectual development, which are determining factors in this integration dimension. The academic integration increase leads to the goals commitment, to the graduation intention and to the persistence growth; and

- Social integration: contemplates the extension of the congruence between the individual and the HEI social system. It also presents two approaches: the development and the frequency of the positive interactions with groups of students existing in the institution (students who live together, study and research groups, sports activities etc.) and with professors, having the opportunity to interact; and the participation in extracurricular activities within the institution. It occurs "in the university institution level" or "in the level of subcultures of an institution".

Tinto (1993) postulates that the academic and social dimensions of the integration influence, subsequently, the commitment with the institution and with the course graduation intention. External aspects, such as professional work elements, financial elements and other 
public external elements, also influence on the student's commitment (WETZEL; O'TOOLE; PETERSON, 1999).

The "Student Integration Model" shows itself to be one of the most influencing models of clients-students' retention in higher education (METZ, 2004). However, several authors criticize the model.

Cabrera, Nora and Castaneda (1993), when testing the model, identified some individual external factors that have a significant role in the deflection decisions, such as students' family responsibilities, finances (capacity of paying for the course) and professional work journey, suggesting a model that would also consider these points.

McCubbin (2003) identified that the model is not adequate to discuss the relationship between persistence and deflection. Hennig-Thurau, Langer and Hansen (2001, p.333) highlight that the model focuses only on behavioral aspects of the students as determining factors concerning loyalty, disregarding the attitudinal aspects.

\subsubsection{RQSL (Relationship Quality-based Student Loyalty) Model}

When visualizing the student's loyalty in higher education, the HEI must search for long-term goals through the intimate relationship with the student, being highlighted among them the student's transformation into an institution "recommender" agent, a raiser of the institution reputation before the society and an opinion leader of the institution service quality due to its commitment (MARZO-NAVARRO; PEDRAJA-IGLESIAS; RIVERA-TORRES,

2005). Moreover, it is expected that the student remains in the institution after his graduation to take part in post-graduation and extension courses (HEGELSEN; NESSET, 2007a; 2007b).

Presupposing that, Hennig-Thurau, Langer and Hansen (2001) created the RQSL (Relationship Quality-based Student Loyalty) Model, which brings three complex constructs as determining factors of the students' loyalty: commitment, noticed quality and reliance.

Figure 4 presents the graphic visualization of the RQSL model, of Hennig-Thurau, Langer and Hansen (2001). As we can observe, the RQSL Model consists of the integration between the "Relationship Quality Model" (HENNIG-THURAU; KLEE, 1997) and the “Student's Integration Model" (TINTO, 1993). 


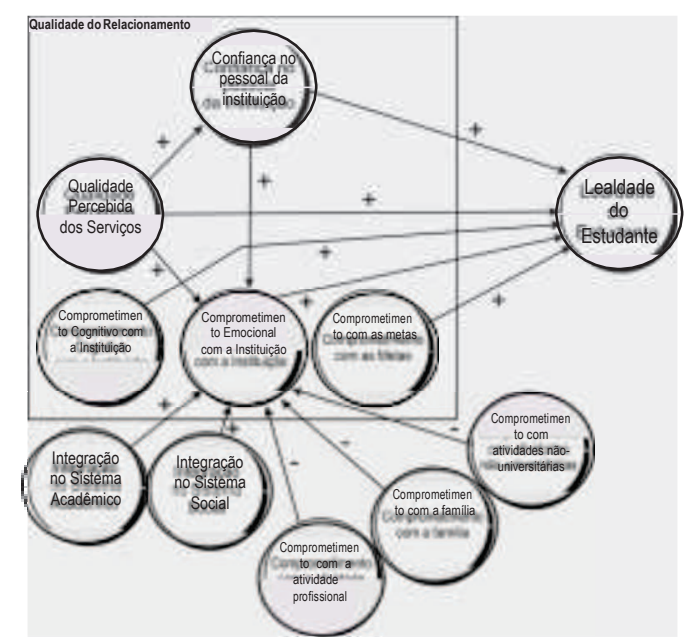

Figure 4 - RQSL (Relationship Quality-based Student Loyalty) Model Source: Adapted from Hennig-Thurau, Langer and Hansen (2001)

One of the limitations of the model is that it needs applications in different markets and kinds of institutions. Several authors mention the model, although they do not apply or adapt it to their realities.

Another point is the need of the financial aspects insertion in the model (such as scholarships, payment capacity or maintenance done for parents or people in charge of the student), in order that these aspects are identified as impacting in the student loyalty. Finally, the organizational culture of the HEI may be a huge influencer of loyalty. Issues such as flexibility, bureaucracy level, confessional and communitarian HEIs, may cause impacts on the clients-students' persistency/deflection decisions.

\section{METHODOLOGY}

The present paper consists of an investigative and theoretical research, with qualitative character. From the theoretical revision carried out, the premises and hypotheses for the Model of Students Loyalty and Retention for Higher Education were determined.

Finally, the attributes that influence the higher education institutions clients-students' retention and loyalty decision were identified and detailed. It is important to emphasize that this model was elaborated based ob the RQSL model, proposed by Hennig-Thurau, Langer and Hansen (2001) and on the Student Integration Model, proposed by Tinto (1993).

\section{RESULTS AND DISCUSSIONS}

The Model of Students' Loyalty and Retention for Higher Education Institutions was elaborated based on the following premises: 
According to the RQSL Model, the educational and demographic data about the students may affect the force of the relationships between the relationship quality and the student's loyalty dimensions (HENNIG-THURAU; LANGER; HANSEN, 2001). Thus, it is convenient that the Students' Loyalty and Retention Model characterizes the student better, segmenting the client-student through educational and demographic data;

The client-student retention through loyalty is directly affected by the higher education institution performance in the loyalty antecedents, proposed by the "Relationship Quality Model", of Hennig-Thurau and Klee (1997);

The most complex variable proposed by the RQSL model is the students' commitment with the HEI, which is divided in two approaches, according to Fullerton (2003): cognitive commitment and commitment with the students' final goal. These variables must be contemplated by the Model of Students Loyalty and Retention for Higher Education Institutions; and

For Tinto (1993), the emotional commitment is determined by the students' integration level with two systems: the university and the non-university system. The university system has two subdivisions, being constituted by the academic system and of the social system. On the other hand, according to Tinto (1993) and to Hennig-Thurau, Langer and Hansen (2001), the aspects related to the non-university system configure a negative influence for the clientsstudents' emotional commitment with the HEI;

A mainly important element in the study of student's loyalty is the satisfaction construct (ANJOS NETO, 2003). According to DeShields, Kara and Kaynak (2005), "satisfied students are needed in order that the institutions goals are reached". Helgesen and Nesset (2007b) emphasize that students tend to develop even more in an institution where they feel well; and

Some researchers mention other factors that influence the student's loyalty, such as the student's influence on the institution's recommendation and reputation (LIN; TSAI, 2006, p.399).

According to the premises and hypotheses raised, the Model of Student's Loyalty and Retention for Higher Education Institutions presents the following variables:

- Independent variables: satisfaction, noticed quality, social integration, academic integration and cognitive commitment, with the goals, with professional activities, family and non-university activities; 
- Dependant variables: loyalty, reliance and emotional commitment, as dependant variables.

These premises are derived in hypotheses, presented on Chart 1.

\begin{tabular}{|c|c|}
\hline HYPOTHESES & DESCRIPTION \\
\hline $\begin{array}{l}\text { The noticed quality positively } \\
\text { influences the client-student } \\
\text { loyalty. }\end{array}$ & $\begin{array}{l}\text { - Involves the evaluation of the services rendered by the HEI regarding the structure: } \\
\text { library, computers, facilities, besides academic staff quantity, competence and } \\
\text { diversity } \\
\text { - Comprises the process relating to education: courses diversity and quality, } \\
\text { administrative services, way of evaluation, relationship with professors, monitors, } \\
\text { research groups. }\end{array}$ \\
\hline $\begin{array}{l}\text { The reliance positively } \\
\text { influences the client-student } \\
\text { loyalty. }\end{array}$ & $\begin{array}{l}\text { - Based on the personal experiences each student has with the professors and } \\
\text { professionals connected to the educational process, comprising the professor safety } \\
\text { themes noticed in the classroom when teaching, passing exams compatible with } \\
\text { that was taught in the classes, using current examples, providing conferences and } \\
\text { lectures given by the teaching body, besides being charismatic and close. }\end{array}$ \\
\hline $\begin{array}{l}\text { The cognitive commitment } \\
\text { positively influences the client- } \\
\text { student loyalty. }\end{array}$ & $\begin{array}{l}\text { - Focus on the cost-benefit relationship of persistence in the university chosen, that } \\
\text { is, involves the client-student's perception that it is not worth changing of HEI } \\
\text { because of his practicality relationship with the University. }\end{array}$ \\
\hline $\begin{array}{l}\text { The commitment with the } \\
\text { graduation goal positively } \\
\text { influences the client-student } \\
\text { loyalty. }\end{array}$ & $\begin{array}{l}\text { - The clients-students who enroll in a university course with the actual perspective of } \\
\text { going on with the course and graduating at the end of the term are much more } \\
\text { prone to persistence and, consequently, to loyalty. }\end{array}$ \\
\hline $\begin{array}{l}\text { The client-student's integration } \\
\text { with the higher education } \\
\text { institution's academic system } \\
\text { positively influences his } \\
\text { emotional commitment. }\end{array}$ & $\begin{array}{l}\text { - Embraces the involvement with academic activities in the campus, such as courses, } \\
\text { events, academic groups (students' councils and research groups) and other } \\
\text { extracurricular activities offered by the HEI. }\end{array}$ \\
\hline $\begin{array}{l}\text { The client-student's integration } \\
\text { with the higher education } \\
\text { institution's social system } \\
\text { positively influences his } \\
\text { emotional commitment. }\end{array}$ & $\begin{array}{l}\text { - Involves the socialization and intensive contact of the student with other students of } \\
\text { the campus, through sports activities, interest groups and dwelling for students who } \\
\text { share the expenses. }\end{array}$ \\
\hline $\begin{array}{l}\text { The client-student commitment } \\
\text { with other non-university } \\
\text { activities negatively influences } \\
\text { his emotional commitment. }\end{array}$ & $\begin{array}{l}\text { - It is external positions that influence the client-student over which the institution, at } \\
\text { first, does not exercise any control. The theory lists as consistent negative } \\
\text { influences: professional activities and a strong relationship with the family and } \\
\text { entertaining activities } \\
\text { - The professional activities exercised by the student may have a negative impact on } \\
\text { the persistence, due to study dedication issues. } \\
\text { - Tinto (1993) says that the student that has family responsibilities tends to deflect } \\
\text { - The entertainment activities and hobbies may demand a lot of time from the } \\
\text { student, leading him to deflection. }\end{array}$ \\
\hline $\begin{array}{l}\text { The client's satisfaction } \\
\text { positively influences the client- } \\
\text { student loyalty. }\end{array}$ & $\begin{array}{l}\text { - Marzo-Navarro, Pedraja-Iglesias and Rivera-Torres (2005) show the satisfaction as } \\
\text { an element essential to the student's loyalty, being important the student's } \\
\text { satisfaction approach with the following variables: } \\
\text { - teaching body: coordination between professors; professors' attitude towards } \\
\text { students; teaching body quality; } \\
\text { - academic support: teaching method; Curriculum frameworks; theory-practice } \\
\text { proportion; Teaching plans; } \\
\text { - course management: respect with the curse plan and agenda; course organization } \\
\text { adequacy; effectiveness of the coordinators' functions; } \\
\text { - administrative support: proper registration and payment processes; convenientterms; } \\
\text { - infrastructure: adequacy and quality of the infrastructure offered. }\end{array}$ \\
\hline $\begin{array}{l}\text { Other factors that influence } \\
\text { loyalty }\end{array}$ & $\begin{array}{l}\text { - Reach of the student's expectations } \\
\text { - HEI image and reputation }\end{array}$ \\
\hline
\end{tabular}

Chart 1 - Hypotheses of The Model Of Students' Loyalty And Retention For Higher Education Institutions

Source: Elaborated by the authors

Thus, the Model of Students Loyalty and Retention for Higher Education Institutions is structured in two parts. The first one deals with issues referring to personal and academic 
information about the respondent and must be configured in the form of questionnaire (MALHOTRA, 1999). Chart 2 summarizes the variables covered:

\begin{tabular}{|c|c|}
\hline VARIABLE & DESCRIPTION \\
\hline Personal Information & $\begin{array}{ll} & \text { Age } \\
- & \text { Gender } \\
\text { - } & \text { Marital status } \\
\text { - } & \text { Number of children } \\
\text { - } & \text { Race } \\
\text { - } & \text { Responily income } \\
\text { - } & \text { Working hours }\end{array}$ \\
\hline Academic Information & $\begin{array}{ll}\text { - } & \text { Type of registration } \\
\text { - } & \text { Previous school } \\
\text { - } & \text { Academic semester in course } \\
\text { - } & \text { Shift }\end{array}$ \\
\hline
\end{tabular}

Chart 2 - Personal and Academic Information

Source: Elaborated by the authors

The second part comprises the dependent and independent variables. The relationship between the issues raised in the data collection instrument, focusing on each of the variables of the proposed model, are presented in Chart 3:

\begin{tabular}{|c|c|}
\hline VARIABLE & RELATIVE QUESTIONS \\
\hline Loyalty & $\begin{array}{l}\text { - I would recommend the HEI for another person } \\
\text { - I am very interested in keeping in touch with my HEI after my course conclusion } \\
\text { - If I was to choose again, I would choose this HEI } \\
\text { - I I am interested in being part of a group of ex-students of this institution } \\
\text { - If I heard anyone negatively criticizing this HEI, I would argue in favor of it } \\
\text { - I am in this HEI for convenience }\end{array}$ \\
\hline Noticed Quality & $\begin{array}{l}\text { - } \quad \text { Professors Body } \\
\text { - } \quad \text { Academic Support Personnel (Coordinators, Directors and other professionals) } \\
\text { - } \quad \text { Care with the students (courtesy and empathy, on the part of the professors) } \\
\text { - } \quad \text { Leaching infrastructure (classrooms, school building) } \\
\text { - } \quad \text { Access to Technology (computer lab, internet, intranet) } \\
\text { - } \quad \text { Administrative Services (treasurer, secretariats); } \\
\text { - } \quad \text { Evarriculum frameworks } \\
\text { - } \quad \text { Insertion in the Labor Market }\end{array}$ \\
\hline Reliance & $\begin{array}{l}\text { - The HEI shows integrity in its actions and conducts } \\
\text { - It is clear that the employees are always acting in the student's interest } \\
\text { - I totally rely on the employees and professors of the HEI } \\
\text { - } \quad \text { I can notice that the HEI is flexible }\end{array}$ \\
\hline $\begin{array}{c}\text { Emotional } \\
\text { Commitment }\end{array}$ & $\begin{array}{l}\text { - I feel very emotionally connected to my HEI (friendships created, affective relationships, } \\
\text { professional life initiated from the HEI) } \\
\text { - } \quad \text { I am proud for studying in this HEI } \\
\text { - } \quad \text { TO be in this HEI is very important to me } \\
\text { - } \quad \text { I feel committed to my HEI }\end{array}$ \\
\hline Satisfaction & $\begin{array}{l}\text { - } \text { In general terms, I am satisfied with this HEI } \\
\text { - } \quad \text { My expectations when I got here are fully satisfied } \\
\text { - } \quad \text { I expected more from this HEI } \\
\text { - This HEI charges a fair monthly payment } \\
\text { - } \quad \text { This HEI's image is important in order that I can keep the relationship }\end{array}$ \\
\hline
\end{tabular}


(Continuation)

\begin{tabular}{|c|c|}
\hline $\begin{array}{c}\text { Cognitive } \\
\text { Commitment }\end{array}$ & $\begin{array}{l}\text { - I chose this HEI for practical reasons (proximity, cost, transportation) } \\
\text { - } \quad \text { I do not leave this HEI because it would be very toilsome to go to another } \\
\text { - } \quad \text { To be in this HEI is important. It would be very uncertain to go to another }\end{array}$ \\
\hline $\begin{array}{l}\text { Commitment with the } \\
\text { Graduation Goal }\end{array}$ & $\begin{array}{l}\text { - When I set one goal to my life, I always achieve it } \\
\text { - } \quad \text { I entered the administration course because I want to continue in this profession }\end{array}$ \\
\hline $\begin{array}{l}\text { Academic } \\
\text { Integration }\end{array}$ & $\begin{array}{l}\text { - My HEI offers many opportunities of academic events and extracurricular courses } \\
\text { - When evaluating my grades and performance in the disciplines, I consider myself to be a } \\
\text { great student } \\
\text { - I participate in academic groups (research groups, students' councils etc.) } \\
\text { - I always visit the library } \\
\text { talks }\end{array}$ \\
\hline $\begin{array}{c}\text { Social } \\
\text { Integration }\end{array}$ & $\begin{array}{l}\text { - My HEI carries out many social and students integrating events } \\
\text { - } \quad \text { when there are social events, I always take part in them } \\
\text { - I have many friends among my classmates } \\
\text { - I am part of study groups together with some classmates } \\
\text { - I keep regular contact with classmates outside the HEI }\end{array}$ \\
\hline $\begin{array}{l}\text { Commitment with } \\
\text { Other Activities }\end{array}$ & $\begin{array}{l}\text { - I consider my hobbies, pastimes and leisure activities a very important part of my life } \\
\text { - When there is an event or meeting that interests me, as leisure, entertainment or related to } \\
\text { my hobby, I hesitate to attend classes } \\
\text { - I am always in direct touch with my immediate family } \\
\text { - I am the direct responsible for my family (couple and children) } \\
\text { - My family has a good higher education history } \\
\text { - I work in order to pay for my university course } \\
\text { - I feel that my job disturbs me in relation to the studies; }\end{array}$ \\
\hline
\end{tabular}

Chart 03: Model variables Loyalty and Retention of Students for Higher Education Institutions

Source: Elaborated by the authors

The variable pertaining to the second part must be organized in a measurement scale (BARBETTA, 2003), being suggested the use of the Likert scale. In such scale, the interviewees indicate their agreement or disagreement level in relation to each of the statements presented. It is suggested the implementation of the five points scale, varying from (1) "I totally disagree" to (5) "I totally agree".

\section{FINAL CONSIDERATIONS}

The aim of the present paper was to create a model to measure the student's loyalty and retention in Brazilian higher education institutions. As a result, it was developed the Model of Students' Loyalty and Retention for Higher Education Institutions, based on the RQSL model, proposed by Hennig-Thurau, Langer and Hansen (2001) and on the Student's Integration Model, proposed by Tinto (1993).

As a result, it is important to firstly highlight that loyalty is an attitudinal state, in which the clients show themselves to be connected and strongly committed to the organizations, not only propagating and defending the institution, but also resisting a deflection. The theoretical referential presented the benefits of the loyal clients, not only in the short and medium-terms 
(in relation to finances), but mainly in the long-term (preserved clients). Thus, it is recommended that the higher education institutions try to observe the client-student's loyalty as a strategic marketing goal.

Secondly, the Model of Students' Loyalty and Retention may be a viable means of investigating if there is the loyalty propensity on the part of the client-student, in higher education institutions, to the extent that it details the attributes that influence the clientstudents' loyalty and retention decision, highlighting among them: satisfaction, noticed quality, social integration, academic integration, cognitive commitment, commitment with the graduation goal, commitment with the professional activities, commitment with the family, commitment with non university activities, emotional commitment, reliance and loyalty.

The understanding of the factors that influence loyalty may contribute for the higher education institutions to establish proper strategies for the retention of the student in the chosen HEI, in order that the student positively corresponds to each of the factors identified.

As a limitation, we can emphasize that the model needs to be tested in practice, being identified the variables with greater force. Therefor, in future works, it is suggested that the model is tested through the realization of a multiple regression analysis in a sample statistically valid.

\section{BIBLIOGRAPHIC REFERENCES}

AKARAPANICH, Sasiwan. Comparing customer loyalty intentions using trust, satisfaction, and commitment of online MBA students versus traditional MBA students. Dissertação, Doutorado em Administração, H. Wayne Huizenga School of Business and Entrepreneurship. Nova Southeastern University, Fort Lauderdale, 2006.

ANJOS NETO, Mário R. Construção e Teste de um Modelo Teórico de Marketing de Relacionamento para o Setor de Educação. Dissertação, Mestrado em Administração, Programa de Pós-Graduação em Administração. Universidade Federal de Pernambuco, Recife, 2003.

BARBETTA, Pedro Alberto. Estatística Aplicada às Ciências Sociais. 5.ed. Florianópolis: Editora UFSC, 2003. 283p.

BARLOW, Janelle; MAUL, Dianna. Emotional Value: creating strong bonds with your customers. San Francisco: Berrett-Koehler Publishers, 2000. 310p.

BERGER, Paul D.; NASR, Nada I. Customer lifetime value: marketing models and applications. Journal of Interactive Marketing. v.12, n.1, p.17-30, 1999.

BIAZUS, Cleber Augusto. Sistema de fatores que influenciam o aluno a evadir-se dos cursos de graduação da UFSM e na UFSC: Um estudo no curso de Ciências Contábeis. Tese 
Doutorado em Engenharia de Produção, Depto. de Engenharia de Produção e Sistemas, Universidade Federal de Santa Catarina, Florianópolis, 2004.

BRAXTON, John M.; HIRSCHY, Amy S. Theoretical Developments in the Study of College Student Departure. In.: SEIDMAN, Alan (ed.). College Student Retention: formula for student success. Westport, CT: Greenwood Publishing Group, 2005. 364p.

CABRERA, Alberto F.; NORA, Amaury; CASTANEDA, Maria B. College persistence: structural equations modeling test of an integrated model of student retention. Journal of Higher Education. v.64, n.2, p.123-139, 1993.

CLANCY, Kevin J.; SHULMAN, Robert S. Marketing Myths that are Killing Business: the cure for death wish marketing. New York: McGraw-Hill, 1995. 308p.

CROSBY, Lawrence A.; EVANS, Kenneth R.; COWLES, Deborah. Relationship quality in services selling: an interpersonal influence perspective. Journal of Marketing. v.54, n.3, p.68$81,1990$.

CZARNIAWSKA, Barbara e GENELL, Kristina. Gone Shopping? Universities on their way to market. Scandinavian Journal of Management. v.18, p.455-474, 2002.

DESHIELDS JR, Oscar; KARA, Ali; KAYNAK, Erdener. Determinants of business student satisfaction and retention in higher education: applying Herzberg's two-factor theory. International Journal of Educational Management, v.19, n.2, p.128-139, 2005.

DESJARDINS, Stephen L. Event History Methods: conceptual issues and an application to student departure from college. In.: SMART, John C. (ed.). Higher Education: handbook of theory and research, v.18. Dordrecht, Holanda: Kluwer Academic Publishers, 2003. 748p.

DWYER, F. Robert; SCHURR, Paul H. OH, Sejo. Developing buyer-seller relationships. Journal of Marketing. v.51, n.2, p.11-27, 1987.

EVANSCHITZKY, Heiner; WUNDERLICH, Maren. An examination of moderator effects in the four-stage loyalty model. Journal of Service Research. v.8, n.4, p.330-345, 2006.

FORNELL, Claes; JOHNSON, Michael D.; ANDERSON, Eugene W.; CHA, Jaesung; BRYANT, Barbara Everitt. The American Customer Satisfaction Index: nature, purpose, and findings. Journal of Marketing. v.60, n.4, p.7-18, 1996.

FULLERTON, Gordon. When does commitment lead to loyalty? Journal of Service Research. v.45, n.4, p.333-344, 2003.

GAIOSO, Natalícia. O Fenômeno da Evasão Escolar na Educação Superior no Brasil. Brasília: Universidade Católica de Brasília, 2005.

GONÇALVES FILHO, Cid; GUERRA, Renata Souza; MOURA, Alexandre Inácio. Mensuração de satisfação, qualidade, lealdade, valor e expectativas em instituições de ensino superior: um estudo do modelo ACSI através de equações estruturais. In.: Encontro da Associação Nacional de Pós-Graduação e Pesquisa em Administração. Anais... 27, Atibaia, 2003. 
GREMLER, Dwayne D.; BROWN, Stephen W. The loyalty-ripple effect: appreciating the full value of costumers. International Journal of Service Industry Management. v.10, n.3, p. 271-291, 1999.

GRIFFIN, Jill. Como conquistar e manter o cliente fiel: transforme seus clientes em verdadeiros parceiros. São Paulo: Futura, 1998.

GRÖNROOS, Christian. The relationship marketing process: communication, interaction, dialogue, value. Journal of Business \& Industrial Marketing. v.19, n.2, p.99-113, 2004.

HEGELSEN, Øyvind; NESSET, Erik. Images, satisfaction and satisfaction: drivers of student loyalty? A case study of a Norwegian University College. Corporate Reputation Review. v.10, n.1, p.38-59, 2007a.

HEGELSEN, Øyvind; NESSET, Erik. What accounts for student's loyalty? Some fields study evidence. International Journal of Educational Management. v.21, n.2, p.126-143, 2007b.

HENNIG-THURAU, Thorsten; GWINNER, Kevin P.; GREMLER, Dwayne D.

Understanding relationship marketing outcomes: an integration of relational benefits and relationship quality. Journal of Service Research. v.4, n.3, p.230-247, 2002.

HENNIG-THURAU, Thorsten; HANSEN, Ursula. Relationship Marketing: some reflections on the state-of-the-art of the relational concept. In.: HENNIG-THURAU, Thorsten;

HANSEN, Ursula. (eds.). Relationship Marketing: gaining competitive advantage through customer satisfaction and customer retention. Berlin: Springer, 2000, 459p.

HENNIG-THURAU, Thorsten e KLEE, Alexander. The impact of customer satisfaction and relationship quality on customer retention: a critical reassessment and model development. Psychology \& Marketing, v.14, n.8, p.737-764, 1997.

HENNIG-THURAU, Thorsten; LANGER, Markus F.; HANSEN, Ursula. Modeling and managing student loyalty: an approach based on the concept of relationship quality. Journal of Service Research. v.3, n.4, p.331-344, 2001.

HERZOG, Serge. Measuring determinants of student returns vs. dropout/stopout vs. transfer: a first-to-second year analysis of new freshman. Research in Higher Education. v.46, n.8, p.883-928, 2005.

JAMAL, Zainab. Customer fit and customer retention at an internet recommendation site. Paper apresentado na Marketing Science Conference. Erasmus University, Roterdã, 2004.

KOTLER, Philip; ARMSTRONG, Gary. Princípios de Marketing. 9.ed. Rio de Janeiro: Prentice-Hall, 2003. 593p.

KOTLER, Philip; FOX, Karen F. A. Marketing Estratégico para Instituições Educacionais. São Paulo: Atlas, 1994. 444p.

KUMAR, V. Managing Customers for Profit: strategies to increase profits and build loyalty. Upper Saddle River: Pearson Education / Wharton School Publishing, 2007. 296p. 
LANZER, Letícia de Souza. Estratégias de Marketing de Relacionamento para Instituições de Ensino Superior: um estudo de caso na Universidade do Sul de Santa Catarina. Dissertação, Mestrado em Engenharia de Produção, Depto. de Engenharia de Produção e Sistemas, Universidade Federal de Santa Catarina, Florianópolis, 2004.

LILJANDER, Veronica. The importance of internal Relationship Marketing for external relationship success. In.: HENNIG-THURAU, Thorsten; HANSEN, Ursula. (eds.). Relationship Marketing: gaining competitive advantage through customer satisfaction and customer retention. Berlin: Springer, 2000, 459p.

LIMA, Vânia Marques de. Percepções de estudantes de primeiro período sobre o serviço educacional: análise empírica de uma IES privada na cidade do Rio de Janeiro. Dissertação Mestrado Profissionalizante em Administração. Faculdades IBMEC, Rio de Janeiro, 2006.

LIN, Chieh-Peng; TSAI, Yuan Hui. Modeling educational quality and student loyalty: a quantitative approach based on the theory of information cascades. Quality \& Quantity, v.42, n.3, p.397-415, 2006.

MALHOTRA, Naresh K. Marketing Research: an applied orientation. 3.ed. Upper Saddle River, NJ: Prentice-Hall, 1999. 763p.

MARZO-NAVARRO, Mercedes; PEDRAJA-IGLESIAS, Marta; RIVERA-TORRES, Pilar. A new management element for universities: satisfaction with the offered courses. International Journal of Educational Management. v.19, n.6, p.505-526, 2005.

MCCUBIN, Ian. An Examination of Criticisms Made of Tinto's 1975 Student Integration Model of Attrition. Paper não publicado, 2003.

MOORMAN, Christine; ZALTMAN, Gerald; DESHPANDÉ, Rohit. Relationships between providers and users of market research: the dynamics of trust within and between organizations. Journal of Marketing Research. v.29, n.3, p.314-328, 1992.

MURTAUGH, Paul A.; BURNS, Leslie D.; SCHUSTER, Jill. Predicting the retention of university students. Research in Higher Education. v.40, n.3, p.355-371, 1999.

OLIVER, Richard L. A cognitive model of the antecedents and consequences of satisfaction decisions. Journal of Marketing Research. v.17, n.4, p.460-469, 1980.

OLIVER, Richard L. Whence consumer loyalty? Journal of Marketing. v.63, special issue, p.33-44, 1999.

PARASURAMAN, A.; ZEITHAML, Valarie A.; BERRY, Leonard L. SERVQUAL: a multiple-item scale for measuring consumer perceptions of service quality. Journal of Retailing. v.64, n.1, p.12-40, 1988.

PAYNE, Adrian; FROW, Penelope. Services relationship marketing: a sector case study. In.: HENNIG-THURAU, Thorsten; HANSEN, Ursula. (eds.). Relationship Marketing: gaining competitive advantage through customer satisfaction and customer retention. Berlin: Springer, 2000, 459p. 
PAYNE, Adrian; FROW, Penelope. A strategic framework for Customer Relationship Management. Journal of Marketing. v.69, n.4, p.167-176, 2005.

PEREIRA, Fernanda. Determinantes da evasão de alunos e os custos ocultos para as Instituições de Ensino Superior. Tese, Doutorado em Engenharia da Produção. Depto. de Engenharia de Produção e Sistemas, Universidade Federal de Santa Catarina, Florianópolis, 2003.

PRADO, Paulo H. M.; SANTOS, Rubens da Costa. Comprometimento e lealdade: dois conceitos ou duas dimensões de um único conceito? In.: Encontro da Associação Nacional de Pós-Graduação e Pesquisa em Administração. Anais... 27, Atibaia, 2003.

REASON, Robert D. Student variables that predict retention: recent research and new developments. NASPA Journal. v.40, n.4, p.172-191, 2003.

RIVAS, Ronald M.; SAUER, Paul L.; GLYNN, Joseph G.; MILLER, Thomas E. Proactive Student Retention: building an early warning system. Working Paper 2007-04, Richard J. Wehle School of Business. Canisius College. 2007.

ROWLEY, Jennifer. Retention: rhetoric or realistic agendas for the future of higher education. The International Journal of Educational Management. v.17, n.6, p. 248-253, 2003.

SANTOS, Cristiane Pizzutti dos; ROSSI, Carlos Alberto Vargas. Os antecedentes da confiança do consumidor em episódios envolvendo reclamações sobre serviços. In.: Encontro da Associação Nacional de Pós-Graduação e Pesquisa em Administração. Anais... 26, Salvador, 2002.

SCHULZ, Don E. Are we too loyal to our concept of loyalty? Marketing News. v.32, n.13, p.11-13, 1998.

SHAJAHAN, S. Relationship Marketing: texts and cases. New Delhi: Tata McGraw-Hill, 2006. 328p.

SIMPSON, Ormond. The costs and benefits of student retention for students, institutions and governments. Studies in Learning, Education, Innovation and Development, v.2, n.3, p.34-43, 2005 .

SIRDESHMUKH, Deepak; SINGH, Jagdip; SABOL, Barry. Consumer trust, value, and loyalty in relational exchanges. Journal of Marketing. v.66, n.1, p.15-37, 2002.

STRATTON, Leslie; O’TOOLE, Dennis e WETZEL, James. Are the factors affection dropout behavior related to initial enrollment intensity for college undergraduates? Research in Higher Education. v.48, n.4, p.453-485, 2007.

TINTO, Vincent. Dropout from higher education: a theoretical synthesis of recent research. Review of Educational Research. n.45, p. 89-125, 1975.

TINTO, Vincent. Leaving College: rethinking the causes and cures of student attrition. 2 ed. Chicago: University of Chicago Press, 1993. 312p. 
TINTO, Vincent. Taking retention seriously: rethinking the first year of college. NACADA Journal. v.19, n.2, p.5-9, 1999.

WESTBROOK, Robert A.; OLIVER, Richard L. The dimensionality of consumption emotion patterns and consumer satisfaction. The Journal of Consumer Research. v.18, n.1, p.84-91, 1991.

WETZEL, James N.; O’TOOLE, Dennis e PETERSON, Steven. Factors affecting student retention probabilities: a case study. Journal of Economics and Finance. v.23, n.1, p. 45-55, 1999.

WETZELS, Martin; DE RUYTER, Ko; VAN BIRGELEN, Marcel. Marketing service relationships: the role of commitment. Journal of Business \& Industrial Marketing. v.13, n. $4 / 5$, p.406-423, 1998.

WIRTZ, Jochen; BATESON, John E. G. Consumer satisfaction with services integrating the environmental perspective in services marketing into the traditional Disconfirmation Paradigm. Journal of Business Research. v.44, n.1, p.55-66, 1999.

WONG, Amy; SOHAL, Amrik. An examination of the relationship between trust, commitment and relationship quality. International Journal of Retail \& Distribution Management. v.30, n.1, p.34-50, 2002.

YORKE, Mantz e LONGDEN, Bernard. Retention and student success in higher education. Londres: Open University Press, 2004. 212p.

ZEITHAML, Valarie A. Consumer perceptions of price, quality, and value: a means-end model and synthesis of evidence. Journal of Marketing. v.52, n.3, p.2-22, 1988. 